\title{
Recent Status of Groundwater Pollution of Municipal Solid Waste Disposal Site at Urali-Devachi Village in Pune City.
}

\author{
Dhere Amar M. ${ }^{1,}$ Barkade Jagnnath D. ${ }^{2}$ \\ ${ }^{1}$ Assistant Professor, Dept. of Science, SVT College of Home Science (Autonomous), SNDT Women's University, \\ Santacruz (W) Mumbai,Email-prof.amardhere@gmail.com \\ ${ }^{2}$ Assistant Professor and Head Deptt. Of Geography, Raja Shripatrao Bhagwantrao Mahavidyalaya, Aundh Dist- \\ Satara (Affiliated to Shivaji University, Kolhapur)
}

\begin{abstract}
The municipal solid waste (MSW) generation in the Pune city Municipal Corporation (PMC) is among the highest as compare with other mega cities in the India with average $0.400 \mathrm{~kg}$ (ranges from the 0.294 to 0.540 $\mathrm{kg}$ ) of waste being generated per person per day. The present study aims to find the pollution of ground water at Urali-Devachi disposal site of Pune Municipal Corporation (Civic body). However, the result of present study was evaluated with the earlier study conducted in 2013 at the same disposal site by Dhere A. M et al. The data from earlier study reveals that, leachate from unscientific disposal of MSW badly pollute the ground water up to $1 \mathrm{~km}$ periphery while in the present investigation shows that, the nature of some water pollutant (COD, BOD, Bicarbonates, Total Hardness) are increased by 3times than 2009 study. It is concluded that current processing to solid waste was responsible for polluting ground water. However this study recommending for alternative disposal site because of pollution and health concerns of people.
\end{abstract}

Keywords: municipal solid waste, land fill, leachate, ground water pollution.

\section{Introduction}

Pune is one of those rare cities with a twin image that of tradition bound place-generally considered the quintessence of Maharashtra culture and that of modern industries located at a height of about 500 meters above sea level, the city occupies the flood plain of Mula-Mutha rivers called the "Poona Plain" by geomorphologists. The area is surrounded low hill ranges. Most of the vegetation found around the hills today is planted. Small patches of deciduous forests are found in sheltered valleys of Pachgaon, Parvati, Katraj and Sinhgad.The core city is marked by its high densities, narrow roads and paucity of open spaces and also has major share of residential as well as commercial development. Pune has emerged as a focal point of Information Technology as well as Biotechnology developments in India ${ }^{1}$. Today Pune is an industrial metropolis as well as an educational centre. According to World Survey, Pune ranking third position for its fastest urban growth rate ${ }^{2}$. The geo-climatic details are given in table number 1.

The municipal solid waste is heterogeneous in nature and it contains papers, plastics, rags, metals, glass pieces, ashes and compatible matters. In addition other substances like scrap materials, waste papers, dead animals, discarded chemicals, paints, hazardous hospital waste and agricultural residue are also categorised in municipal solid waste $^{3}$. Till date, the biomedical waste generated from clinics, hospitals, nursing homes, pathological laboratories, blood banks and veterinary centers have also been disposed along with municipal solid waste at dumpsite ${ }^{4}$.In Indian cities solid waste generation rate is increases. The average per capita solid waste generation in India has increase from $0.32 \mathrm{~kg} / \mathrm{day}$ in $1971-73$ to $0.556 \mathrm{~kg} / \mathrm{day}$ in $2009-2010^{5}$. Daily per capita generation of municipal solid waste in India ranges from about $100 \mathrm{gm}$ in small towns to $500 \mathrm{gm}$ in large towns ${ }^{6}$.

\section{Pune Municipal Solid Waste-}

From its inception in 1950 Pune Municipal Corporation handle, manage and dispose daily generated solid waste. The civic body of Pune Municipal Corporation governs through the Bombay Provincial Municipal Corporation Act, 1949. The General Body, Standing Committee and Municipal Commissioner govern the all its operations. The annual budget of Rs.3,196.12 crore put by the Pune Municipal Corporation7.Solid waste is the most important step in waste management and is done in two major categories i.e. dry and wet garbage. From $1^{\text {st }}$ July, 2005 Pune Municipal Corporation starts waste segregation process. PMC forced resident to segregate dry and wet waste. PMC done ground reality in 14 wards regarding solid waste segregation practice in 8 categorized places namely societies, bungalows, slums, colony, hotels, restaurants, juice bars, wedding halls, hostels, slaughter houses and shops. Study by Gidd M.R. et $\mathrm{al}^{8}$ shows that waste segregation is not been uniform in all wards and categories. 
Issues of Groundwater Pollution of Municipal Solid Waste Disposal Site at Urali-Devachi Village in..

In slums waste is segregated well but in hotels only $50 \%$ of waste is segregated. Where as slaughter houses in some words are not segregate its waste. For collection and transportation of solid waste the PMC playing a positive role in door-to-door collection of waste by deploying vehicular fleet as follows :

1) Nearly 450 cycle rickshaws are operating in various parts.

2) 65 Ghanta (Bell) Trucks have reached $60 \%$ properties in doorstep services.

3) Separate system for collection hotel waste with the help of 20 trucks.

Due to augmented doorstep collections services, PMC could achieve in making container free areas by reducing more than 300 containers of 3.8 cubic meters capacity and similar number of compact bucket. For waste collection and transportation, PMC has set up six different ramps at strategic locations in the Pune city. The solid waste from each collection point is brought to those ramps, by dumper placers or other transport equipments. Before sending entire waste to disposal site at Uruli-Devachi, the entire waste is transfer to station for weighing and computerized record is maintained.

All the waste generated in the municipal area is collected and transported to the landfill site. There the waste is dumped and some portions are properly treated. Urauli-Devachi landfill sites are allocated in the 1991 and start the dumping of daily generated solid waste. The capacity of this dumping yard is 29,5000 MT (Metric Tonnes) of waste per annum and spread over 43 hectares ${ }^{9}$. This dumping yard is managed by the PMC however waste recycle plant has been run by private sector to produce compost manure in commercial scale. The landfill at UrauliDevachi has an area of about 43 hectare, out of which about 15 hectare is already filled up and sealed permanently. (Dhere A M, et al 2008) In order to take care of expected population growth following projects decided by Pune Municipal Corporation ${ }^{8}$.

1. Setting up biogas plants on Built Operate Transfer (BOT) basis with a capacity of 50 MTD (Metric Tonnes per Day) of wet waste in decentralized manner.

2. 50 MTD (Metric Tonnes per Day) of Vermi-Compost plant and 500 MTD (Metric Tonnes per Day) of mechanical composting plant.

3. Bio-Compost plant on 1 acre of land.

Pune Municipal Corporation with SWACH doing waste collection work from last four year. SWACH is nonprofit organization by the sweepers and rag pickers. It came into existence in 2007 and became operational in 2008. It is the institutional outcome of the door to door waste collection initiative of the Kagad Kach Patra Kashtakari Panchayat(KKPKP). The initiative brought together the interests of rag pickers /waste collectors in upgrading their livelihoods and municipality's interest in sustainable solid waste management.There are several studies available on the issues of solid waste generation in the Pune Municipal Corporation boundary. All this study put different data of daily waste generation. Study report by PMC named Waste Quantification and Characterization (2006) explains per day solid waste generation is 1093 metric tonnes (MT). The average per capita waste generation in Pune city is 364 grams. The per capita waste generation varies between 229 to 504 grams per day among different wards. This study also put the percent wise solid waste generation from the various sources.

In the PMC wards commercial sector combining the hotels generates $50 \%$ of the total waste. This study further reported that Tilak Road, Vishrambaugwada and Bibvewadi wards are contributing more in waste generation.Study by Santosh Bhailume et al. ${ }^{11}$, reveals the facts of solid waste generation in the Pune city. Per day Pune city generate 885 to 1,200 MT (Metric Tonnes) of solid waste. Per capita waste generation of the city as well as Tilak Road, Vishrambaugwada and Bibvewadi wards is about $294 \mathrm{gm}, 399 \mathrm{gm}$ and $211 \mathrm{gm}$ to 504 gm per day respectively. Vishrambaugh ward has highest population and per capita waste generation is $477 \mathrm{gm} / \mathrm{day}$. Tilak road ward has highest per capita waste generation rate i.e. $601 \mathrm{gm} /$ day. Author argues that, Pune city as a whole generated waste is $445 \mathrm{gm} /$ capita/day, which is higher than the standards i.e. $400 / \mathrm{capita} /$ day by Central Pollution Control Board. Within the Pune city per day generating rate of solid waste reaches around 1,100 metric tonnes ${ }^{8}$. The collection, transportation and disposal cost is about Rs. 60 crores per year and nearly Rs. 20 to Rs. 25 crore spent on purchase of vehicles for transportation and maintenance equipments used at the sanitary landfill site ${ }^{8}$. Study by Sanjay Rode ${ }^{5}$ (2011) gives the daily solid waste generation rate of Pune city is 2,602.17 MT (Metric Tonnes).

Pune Municipal Corporation's Strategic Environment Report ${ }^{7}$ (2012-13) gives facts on solid waste generation and management. According to this report municipal solid waste generation in Pune city is among the highest in generating per capita waste Indian cities i.e. $400 \mathrm{gm} / \mathrm{capita} /$ day. Currently about 1,100 metric tonnes solid waste is generated per day. It was unusual to note that, solid waste generation per unit with in the area lies in the old city is very higher than the suburb. They give the explanation because of generation from residential areas and commercial areas are more aggravated in the centre of city. But which is not true sense of justification where as the suburban area rapidly increasing which limits on collection of waste by the Pune Municipal Corporation. It is observed that, majority portion of solid waste are not collected within the newly developed suburban places around 
Issues of Groundwater Pollution of Municipal Solid Waste Disposal Site at Urali-Devachi Village in..

the Pune City ${ }^{10}$.PMC shifted its dumping ground from Kothrud to Urali-Devachi in 1999. Initially it is located 20 kilometer away from the Municipal boundary but now it was just $2 \mathrm{~km}$ because of urbanisation. The dumping ground spread over 43 hectors at Urali-Devachi and another landfill site of 17.5 acres is allocated at Yeolewadi. Disposal site was originally partly stone quarry and had deep excavated areas. The unscientifically disposal is done since $2000^{12}$. (Dhere A.M; et al, 2008) This creates severe ground water infectivity is observed in the wells on the downstream slopes up to 2 kilometer away from disposal site12, 13,14. The non implementation of the MSW Rules 2000 led to Public Interest Litigation (PIL) in Mumbai High Court against the Pune Municipal Corporation by local resident.

From 2003 onwards PMC give landfill contract to ECO Designs India Pvt. Ltd. In this designed landfill site issues related to closure or capping of the existing waste, outlets for landfill gas, stop formation of new leachate and desire to develop a greenery and hockey stadium after closure of this landfill site is well narrated ${ }^{13}$. Along with this designed landfill site composting platform will be constructed of concrete with a layer of $0.5 \mathrm{~mm}$ HDPE liner beneath. According to the ECO Design's report this construction strictly follows the MSW management Rule 2000 norms. This plan is further submitted to the Mumbai High Court by the PMC to resolve PIL. The capacity of this landfill is 79000 square meter and cost is Rs. 4 crore.

In the article ${ }^{13}$ clarify that, after capping this landfill it could easily used to accommodate hockey ground with couple basketball and volley ball courts with areas for a garden and jogging track. But these are fantasy, current status of this landfill site and disposal depot is recognized as 'Hot-Spot of Pollution' in Maharashtra state in general and Pune district in particular. Every year in summer season this disposal that to having constant fire. This fire and smoke continue for week. Till date ground water is highly contaminate due to mixing of leachate from solid waste landfill site.This article is based on the study by Dhere Amar M. et al ${ }^{12}$ published at Journal of Current Science. The attempt is made here to analyse the similar parameter on the basis of present scenario of disposal of municipal solid waste at Urali-Devachi disposal depot. This article reveals the change the situation at municipal solid waste within the eight years i.e. 2005 to 2013.

\section{Materials And Methods}

For determining environmental setting in solid waste landfill site, the following aspects need to be analyzed: Leachate and ground water analysis ${ }^{16}$ - In June 2005 first analysis of all the parameters are conducted. For the confirmation of actual concentration of organic and inorganic contents in the leachate and ground water the same analysis is repeated in period of Dec.2007 to Jan.2008.

1. $\mathrm{pH}$-Digital $\mathrm{pH}$ meter, $\mathrm{AE} 101$ (Acme Electronics)

2. COD [Chemical Oxygen Demand] (mg/lit) - Ferrous Ammonium Sulphide titration methods

3. BOD [Biochemical Oxygen Demand] (mg/lit)- Modified Wrinkler Method

4. TDS (Total Dissolved Solids) (mg/lit)- Quantitative analysis.

5. TSS (Total Suspended Solids) (mg/lit)-Quantitative analysis

6. Corrosion-Saturated Index (SI) of particles

7. Total Alkalinity (mg/lit) - Gravimetric titration method

8. Total Hardness (mg/lit) - EDTA titrimetric method

9. Calcium and magnesium (mg/lit) - Versanate method

10. Carbonate and Bicarbonate (mg/lit) - Gravimetric titration method

11. Chlorides (mg/lit) - Mohr's titration $\left(\mathrm{AgNO}_{3}\right)$

12. Sodium (mg/lit) - Flame photometer (Sorenson)

13. Sulphide (mg/lit) - Spectrophotometer (DR-2000)

\section{Results}

The samples of leachate and ground water have been collected from following locations:

Sample I: Leachate samples collected from percolation tanks No. 1, 2 \&3(Photo No.1)

Sample II: Leachate sample collected from landfill storage tank

Sample III: Well water (Well located 500mts away from landfill site) (Photo No.2)

Sample IV: Well water (Well located 800mts away from landfill site) (Photo No.3)

Sample V: Well water (Well located 1200mts away from landfill site) 
Issues of Groundwater Pollution of Municipal Solid Waste Disposal Site at Urali-Devachi Village in..

Table No.7 Leachate and well water characteristics.

\begin{tabular}{|c|c|c|c|c|c|c|c|c|c|c|c|}
\hline \multirow{2}{*}{$\begin{array}{l}\text { Sr. } \\
\text { No. }\end{array}$} & \multirow[t]{2}{*}{ Parameters } & \multicolumn{10}{|c|}{ Samples (Analysed in year $2005^{* 8}$ and 2013 ) } \\
\hline & & I* & I & II* & II & III* & III & IV* & IV & $\mathbf{V}^{*}$ & $\mathbf{V}$ \\
\hline 1 & $\mathrm{pH}$ & 3.87 & 3.03 & 4.26 & 3.78 & 4.87 & 3.03 & 5.13 & 3.78 & 7.23 & 3.03 \\
\hline 2 & Conductivity $25^{\circ} \mathrm{C}$ at $\mu / \mathrm{cm}^{2}$ & N.M. & N.M. & N.M. & N.M. & 6.24 & N.M. & 8.24 & N.M. & 1.203 & N.M. \\
\hline 3 & COD mg/lit & 78350 & 240050 & 31244 & 95732 & 834 & 3240 & 716 & 2617 & 226 & 810 \\
\hline 4 & BOD mg/lit & 30100 & 107836 & 10112 & 32567 & 703 & 2105 & 412.16 & 1276 & 3.27 & 276 \\
\hline 5 & TDS mg/lit & 740 & 2674 & 817 & 3561 & 940 & 2103 & 1230 & 1898 & 113 & 369 \\
\hline 6 & TSS mg/lit & 25387 & 88098 & 6100 & 33987 & 1129 & 3567 & 521 & 1893 & 51 & 765 \\
\hline 7 & Total Solids mg/lit & 26127 & 90772 & 6917 & 37548 & 2069 & 5670 & 1742 & 3791 & 125 & 1134 \\
\hline 8 & $\mathrm{Ca}+\mathrm{Mg} \mathrm{mg} / \mathrm{lit}$ & 472 & 1045 & 133 & 298 & 25 & 102 & 71 & 122 & 30 & 95 \\
\hline 9 & Bi-carbonates mg/lit & 400 & 1344 & 270 & 702 & 15.4 & 65 & 10 & 43 & 05 & 24 \\
\hline 10 & Sodium mg/lit & 24700 & 48234 & 13716 & 25612 & 2437 & 5691 & 2612 & 5123 & 29.12 & 105 \\
\hline 11 & Chloride $\mathrm{mg} / \mathrm{lit}$ & 10212 & 27851 & 1312 & 3101 & 314 & 952 & 52 & 321 & 36 & 167 \\
\hline 12 & Total Alkalinity $\mathrm{mg} /$ lit & 10800 & 21087 & 1334 & 2781 & 212 & 451 & 62 & 291 & 42 & 143 \\
\hline 13 & Total Hardness $\mathrm{mg} / \mathrm{lit}$ & 40200 & 125491 & 69103 & 190321 & 12134 & 41987 & 3312 & 10765 & 1044 & 5631 \\
\hline 14 & Sulphate $\mathrm{mg} / \mathrm{lit}$ & 140 & 6510 & 18 & 50 & 7.12 & 18 & 7.05 & 15.7 & 2.17 & 10 \\
\hline 15 & Carbonates $\mathrm{mg} / \mathrm{lit}$ & NM & NM & NM & NM & NM & NM & NM & NM & 09 & NM \\
\hline 16 & Test of Corrosivity & $+\mathrm{ve}$ & $+\mathrm{ve}$ & $+\mathrm{ve}$ & $+\mathrm{ve}$ & $+\mathrm{ve}$ & $+\mathrm{ve}$ & $+\mathrm{ve}$ & $+\mathrm{ve}$ & $-\mathrm{ve}$ & $+\mathrm{ve}$ \\
\hline
\end{tabular}

\section{Discussion}

The leachate pond and wells are selection are done based on the earlier study ${ }^{12}$. The leachate and well's water characteristics shown in table number 7. In the earlier study the leachate sample I \& II is acidic and corrosive in nature but recent study shows that, all the samples are turns to acidic and corrosive. The continuous leakage of leachate from the disposal depot turns well water too much acidic. Through this it indicates the seriousness of ground water pollution at Urali-Devachi village. The conductivity of leachate and well water is beyond the measurable limit. This indicates that leachate and well water has high concentration of various salts and minerals. On the other hand study in 2005 shows only leachate samples have high concentration of various salts and minerals. Study in 2005 years revealed that, COD and BOD of leachate sample I \& II were $78350 \mathrm{mg} / \mathrm{lit}, 30100 \mathrm{mg} / \mathrm{lit}$ and $31244 \mathrm{mg} / \mathrm{lit}, 10112 \mathrm{mg} / \mathrm{lit}$ respectively. Though in 2013 year similar parameters of same samples having 240050 $\mathrm{mg} / \mathrm{lit}, 95732 \mathrm{mg} / \mathrm{lit}$ and $107836 \mathrm{mg} / \mathrm{lit}, 32567 \mathrm{mg} / \mathrm{lit}$ respectively. During 8 years (2005-2013) the concentrations of COD and BOD in the leachate increased by three times. Results of both the studies confirms that, sample I leachate has a high amount of organic and inorganic compounds than samples II. As both the leachate samples (I\&II) have higher amount of Total Solids and Chlorides. Total Solids makes leachate more turbid while high Chloride concentrations impart leachate colour orange or dark red. The origin of sulfate in leachate has been due to hydrogen sulfide gas produced during anaerobic digestion of solid waste. In 2005 study Sulphate concentration in leachate sample I \&II is $140 \mathrm{mg} /$ lit and $80 \mathrm{mg} / \mathrm{lit}$ and in 2013 study it was $276 \mathrm{mg} / \mathrm{lit}$ and $125 \mathrm{mg} /$ lit respectively it is lower than maximum limit of IS: $2291^{23}$. It is confirmed that, concentration of all the measured pollutants in the leachate sample are increased in the later study. From this, this is clearly ascertained the percolating leachate has high concentration of various pollutants and this is only source for the contamination of ground water.

In the recent study (2013) all the dug wells are found in the good state. Therefore same samples are analysed to find the concentration of various pollutants. Sample III collected from well that is $500 \mathrm{mts}$ away from disposal site and this water is very much contaminated and greenish blooming are developed which indicates the problem of eutrophication (Photo No.1). In this well water's (sample IV) has heavy pungent smell during field visit. This is clearly proved that still leachate percolating from the disposal site added pollutants in the groundwater. For analyzing the quality of ground water the samples were collected from wells located nearby disposal site. The sample III, IV \& V were collected from wells located 500mts, $800 \mathrm{mts}$ and $1200 \mathrm{mts}$ away from solid waste landfill site respectively. The well water sample III \& IV's pH and conductivity value indicates the spread of leachate around the disposal site at Urali-Devachi village. Till date leachate spread around the periphery of disposal area and it pours the contaminant to pollute the ground water.

When earlier study carried out the amount of COD and BOD in the sample III is $834 \mathrm{mg} / \mathrm{lit}$ and $703 \mathrm{mg} / \mathrm{lit}$ respectively. This is incredibly goes up to $3240 \mathrm{mg} / \mathrm{lit}$ and $2105 \mathrm{mg} / \mathrm{lit}$ in year 2013 . The amount of Sodium in sample III is $2437 \mathrm{mg} / \mathrm{lit}$ (2005) which is amplified to $5619 \mathrm{mg} / \mathrm{lit}$ (2013). Similarly in 2005 year COD and BOD concentration in well water sample IV is $716 \mathrm{mg} / \mathrm{lit}$ and $412.16 \mathrm{mg} / \mathrm{lit}$ respectively. While in later study, same parameter value is grown to $2617 \mathrm{mg} / \mathrm{lit}$ and $1276 \mathrm{mg} / \mathrm{lit}$ respectively. Hence, it is verified that COD, BOD and Sodium concentrations in well water sample III and IV are higher than IS: $2291{ }^{23}$ in study conducted after 8year. In the sample $\mathrm{V}$ concentration of all the pollutants are increased by many times. In the earlier study ${ }^{12}$ researchers concluded that, percolation and spreading of leachate in ground has certain limitations. But this notion is failed after 
Issues of Groundwater Pollution of Municipal Solid Waste Disposal Site at Urali-Devachi Village in..

analysis of this well water in later study. Because COD and BOD value of the Sample V is $810 \mathrm{mg} / \mathrm{lit}$ and $276 \mathrm{mg} /$ lit where COD is 4 times higher and BOD is 100 times higher than the earlier result. The concentration COD and BOD in the well water located 1200 meter away from the disposal site was higher than the permissible limit ${ }^{24}$. In another study ${ }^{14}$ it was found that, permeable rocks was found within the Municipal Disposal Site which creates an ideal conditions for to percolate leachate and travel up to long distance. Following of the 2013 study, it is discovered that, well water are not suitable for drinking, outdoor bathing, propagation of wild life, industrial cooling and even not for irrigation. The Pune Municipal Corporation's solid waste disposal and management practice still creates the problem of air pollution and ground aquifer pollution up to 1200 meter in and around the Urali-Devachi village. Still operating the Hunjer Plant for safe disposal of municipal solid waste have its limitations. Therefore, PMC needs to improve its present municipal solid waste disposal practice towards environmental friendly. Because not only due to pollution problem but also continuous quarrel between villagers of Urali-Devachi and municipal authority during past 5 years.

\section{Conclusion And Suggestions}

After massive efforts Pune Municipal Corporation fails to safely dispose daily the generated unsegregated municipal solid waste. Although the disposal isn't been stop at the present disposal site which having many environmental problems. It is further concluded that, PMC have to stop further disposal at Urali-Devachi disposal site and find the alternative place and declare Urali-Devachi disposal site Hot-Spot of air and water pollution Earlier study ${ }^{12}$ proposed several suggestions including waste recycling and waste reduction. But after 8 years it was not seen at any stage either by PMC and any local NGO. The NGO like SWACH is only recycled up to $13 \%$ of total waste. Following are the things may suit to reduce the intensity of pollution.

1) PMC needs to start awareness drive to appeal resident for waste segregation and its significance for environmental friendly disposal. Waste should be collected separately on three categories i.e. Residual, Recyclable and Biological categories.

2) Promote Bio-methanation and Bio-compost projects to dispose the wastes generated from the hotels, restaurants, vegetable markets, snack centres, slaughter houses and temples.

3) Like Agartala City ${ }^{25}$ waste should be treated in three tiered structure: Recover and Recycling from waste, Biological Technology and Thermal Treatment.

4) PMC should search alternative land ${ }^{26}$ scientific treatment and then disposal of daily generated solid waste generated by the Pune Municipal Corporation. The environmental conditions of Urali-Devachi village is very bad because there may require more time to stabilize the air quality around the disposal site.

\section{References}

[1]. MCCIA., Profile and analysis of Pune manufacturing Inc. An Intelligence report on Solid Waste Management in Pune City, Pune, 2000,pp.2-12.

[2]. Vikalpvedh, Punyacha viaskache varasdar, Samarth Baharat Vyaspeeth, 2008, 27.

[3]. Bhide A.D. and Sudershan, Solid Waste Management in Developing Countries, Indian National Scientific Documentation Centre, NewDelhi, 1983,pp123-154.

[4]. Dhere Amar M., Biomedical waste management: A case study of YCM hospital in pune. In Proceedings of the Second National Conference on Urban, industrial and Hospital Waste Management, Saket Project Ltd., Surat 2011.

[5]. Rode Sanjay, Integrated approach to solid waste management in Pune city. MPRA Paper No.32137. Available at http://mpra.ub.unimuenchen.de/32137/. Access on 2 Oct 2011.

[6]. Yadav Kushal Pal S., Pandora's Garbage Can, CES Down To Earth, March 15, 2007, 20-21.

[7]. Environmental Status Report, Pune Municipal Corporation, 2013.

[8]. Gidde M R, Todkar V V, Kokate K K, Municipal solid waste management in emerging cities: a case study of Pune city. In: Proceeding of Indo Italian Conference on Green and Clean Environment. March 20-21, MAEER's MIT College of engineering Pune, 2008.

[9]. Anagal V Sustainable urban solid waste management- a case study of Pune. In: $10^{\text {th }}$ National Conference on Technological Trends, 6-7 Nov, 2009.

[10]. Dhere Amar M.and Patil Dhanraj A., Diagnosis of Solid Waste Handling and Management practices in Pune City, India. Present status and challenges for International Cooperation on Urban Solid Waste Management in Asian Mega and Large Cities, Japan International Cooperation Agency, June,2012,301-359.

[11]. Santosh Bhailume, Virendra Nagarale, Parviz Gohjogh Najad., A Geographical study of Civic amenities in PMC area using GIS techniques. http://http://isrj.org/ArchiveArticle.aspx?ArticleID=352Access on 4 Oct 2009.

[12]. Dhere A M, Pawar C B, Patil D A, Pardeshi P B., Municipal solid waste disposal in Pune city- an analysis of air and ground water pollution. Current Sci. 95(6): 773-777.

[13]. Purandare A N., Design and construction of closure and new landfill for Pune city- A case study. In: workshop on Sustainable Landfill Management, Chennai, 3-5 December, 2003.

[14]. Karanje S and More R., Municipal solid waste site Urali-Devachi-the present reality. Project report for the M.Sc. (Geo-Informatics) submitted to Dept. of Geography University of Pune, 2009.

[15]. Katz M, Measurement of Air pollution guide to the selection of methods WHO, Geneva, 1969,149-155. 
Issues of Groundwater Pollution of Municipal Solid Waste Disposal Site at Urali-Devachi Village in..

[16]. APHA, Standard Methods for examination of water and waste water, American Public Health Association AWWA WCPF, Washington, $17^{\text {th }}$ Edition, 1989.

[17]. The India Express, Pune News Line, Urali- Devach Fire Depto Kept Fire, 27May,2006, 3.

[18]. Permissible limits of Ambient Air pollutants, Central Pollution control Board, New Delhi available at http:/ /cpcb. delhi. nic.in/ standard18. hmt accessed on 2nd June 2013.

[19]. Trevedi P.R. \& Raj G., Solid Waste Pollution, Akashdeep Publishing House, New-Delhi, 1992.

[20]. Schaefer, G., Hamilton, W., \& Mathai, C. V. Implementing the revised NAAQS and the FACA subcommittee for ozone, particulate matter and regional haze. Environ. Man, 1997, 23, 22-28.

[21]. Patil D.A., Pawar C.B and Dhere A.M., Environment Education, Phadke Publication, Kolhapur, 2006, 34-56.

[22]. El-Fadel M., Findikakis A. N. \& Leckie J. O., Environmental Impact of Solid Waste Land Filling, Journal of Environmental Management, 50, 1971, 1-25.

[23]. IS: 2291, Indian Standard, Criteria for classification of Inland Surface Water, Indian Standard Institute (ISI), New-Delhi, 2000.

[24]. Lemos, M. C., \& Agrawal, A. Environmental governance. Annu. Rev. Environ. Resour., 2006,31, $297-325$.

[25]. Milind Ramtake, Report on Solid Waste Management under Agartala City. Available at http:// www. nswaienvis. nic.in/ Waste_ Portal/Case_Studies_31.10.14/Case\%20Study\%20on\%20Solid\%20Waste\%20Management\%20under\%20Agaratla\%20city.PDF accessed on $5^{\text {th }}$ September, 2015.

[26]. Suchitra M., Out side: Brunt or Buried, Garbage needs land, CSE Down To Earth, March15, 2007, 22-24.

[27]. Colon, M. and Fawcett, B., Community-based Household Waste Management: Lessons Learnt from EXNORA's 'Zero Waste Management' Scheme in Two South Indian Cities, Habitat International, Elsevier Publications, 2010, 102-132. 